\title{
SEGREGATION AND GENTRIFICATION OF AN INFORMAL SETTLEMENT IN A CITY CENTER
}

\author{
Hani Mardhotillah ${ }^{1}$, Ahmad Gamal $^{1 *}$ \\ ${ }^{1}$ Department of Architecture, Faculty of Engineering, Universitas Indonesia, Kampus UI Depok, \\ Depok 16424, Indonesia
}

(Received: June 2018 / Revised: August 2018 / Accepted: December 2018)

\begin{abstract}
In this research, we investigated the instance of segregation and gentrification in Cikini, a place where formal and informal settlements coexist with walled separation. We conducted a mixedmethods research study using the following: (1) a field survey to observe the physical relationship between the perumahan and kampung settlements; (2) mapping of building age and land use patterns; (3) interviews with key respondents, community leaders, street vendors, and market vendors. We found that residential segregation in Cikini is not based on people's racial identity, but on their socio-economic status. The spatial separation of people from different socio-economic classes cannot simply be understood as inequality. It represents some features of segregation, such as: (1) a fixed physical barrier between the perumahan and kampung, despite mutual social and economic connections between the two; and (2) the fact that there is no permanent residential mobility between the two despite the economic mobility experienced by people in the kampung settlement. Interestingly, we found that kampung settlement does not experience gentrification while the perumahan is slowly gentrifying. We attribute this uniqueness of the kampung settlement to its resilient social fabric.
\end{abstract}

Keywords: Gentrification; Housing; Informal settlement; Kampung; Segregation

\section{INTRODUCTION}

Segregation and gentrification problems occur in every country in the world. Cikini, an informal settlement in Jakarta, epitomizes the segregation and gentrification that occurs in Indonesia. Cikini has two kinds of urban settlements: formal and informal. The difference between the two settlements creates economic and social inequality, which can be seen in the physical separation. Separation occurs because of the differences in economic growth rates which affect the income level of Cikini's residents. As a result, the quality of public facilities and services is poor (Kato, 2012). The poor quality of public service in Cikini decreases the productivity and income of Cikini's informal settlement residents. The disparity in income levels of the informal and the formal settlement residents creates social problems in the society.

Social problems in lower-class societies create another problem: evictions. The eviction does not happen directly through expulsion. However, without government regulations to protect the informal settlement that has low property prices, investors can develop the area without considering the community's needs.

\footnotetext{
*Corresponding author's email: gamal@eng.ui.ac.id, Tel. +62-21-7863512, Fax. +62-21-7863514 Permalink/DOI: https://doi.org/10.14716/ijtech.v9i7.2519
} 
The level of economic growth in a region depends on its people's skills level. The difference in people's skills level in a region can affect production processes. The development of production processes can, in return, increase the productivity and income of the people that live in that region. Differences in income levels create divisions in economic class (Smith \& Harvey, 1990). The existence of different economic classes illustrates the importance of production process development in accordance with the population's potential.

Production processes can be developed in accordance with the population's potential by using natural resources. Production processes that correspond to the population's skills can increase the community's productivity and income. The increase of the community's income can improve the community's economic class (Smith \& Harvey, 1990).

Area separations within a region are the result of economic divisions in the society. Economic division occurs when there is a change in the required worker skill level due to the development of the production process. Workers with enough skills to operate advanced technology belong to the higher social class, while the workers without these skills belong to the lower social class. This economic division demonstrates how a change in production processes can affect social division. This shows how the development of production processes that are not in line with society's skills can lead to social inequalities (Smith \& Harvey, 1990).

The difference in social class often indicates different levels of economic growth. An increasing economic growth rate can also increase the social gap. Improvements in a community's production process that increases the population's skills can improve the economy of the community. Changes in people's quality of life can also cause changes in social class. The difference in regional economic growth will affect how each region develops (Smith \& Harvey, 1990).

Uneven development creates a division of areas based on economic and social classes. The economic and social disparities create physical boundaries within regions; this phenomenon is called segregation. Discrimination also influences segregation, which, in turn, prevents lowincome people from raising their income (Massey \& Denton, 2012). The separation of informal and formal settlements based on economic and social disparities is a form of segregation and uneven regional development.

Segregation is not only formed as physical boundaries but in non-physical boundaries that prevent low-income people from moving to high-class areas. In the United States, segregation occurs when there is discrimination against low-income people through access (either physical or social) limitation (Wilson, 2012). Access limitation prevents low-income people from getting better jobs and proper public services. Improper public services for low-income people decrease society's productivity (Massey \& Denton, 2012). This affects low-income people because low social productivity means they cannot increase their income. The better their income, the better the area they can live in; if low-income people cannot increase their income, it affects their ability to buy a house (Herbert et al., 2013).

The existence of lower economic classes in the downtown area shows the existence of lowvalue properties among high-value properties. Downtown low-value properties attract investors to invest in those areas. Property development in lower-class areas increases property selling prices and potential increases in property rental rates. If property rates increase because of development, the lower economic class tends to be pushed out (Smith, 1979; Slater, 2017).

Gentrification is a form of regional development that is not only a result of physical development. Gentrification is also the process by which upper-class people invade an area with low property values. Another indication of gentrification is the existence of lower-class living in the downtown area. Segregation and gentrification as forms of uneven development lead to 
the differences in public facilities. The differences in public facilities in a region will create social problems and environmental problems and reduce the society's quality of life (Hardoy \& Satterthwaite, 1991).

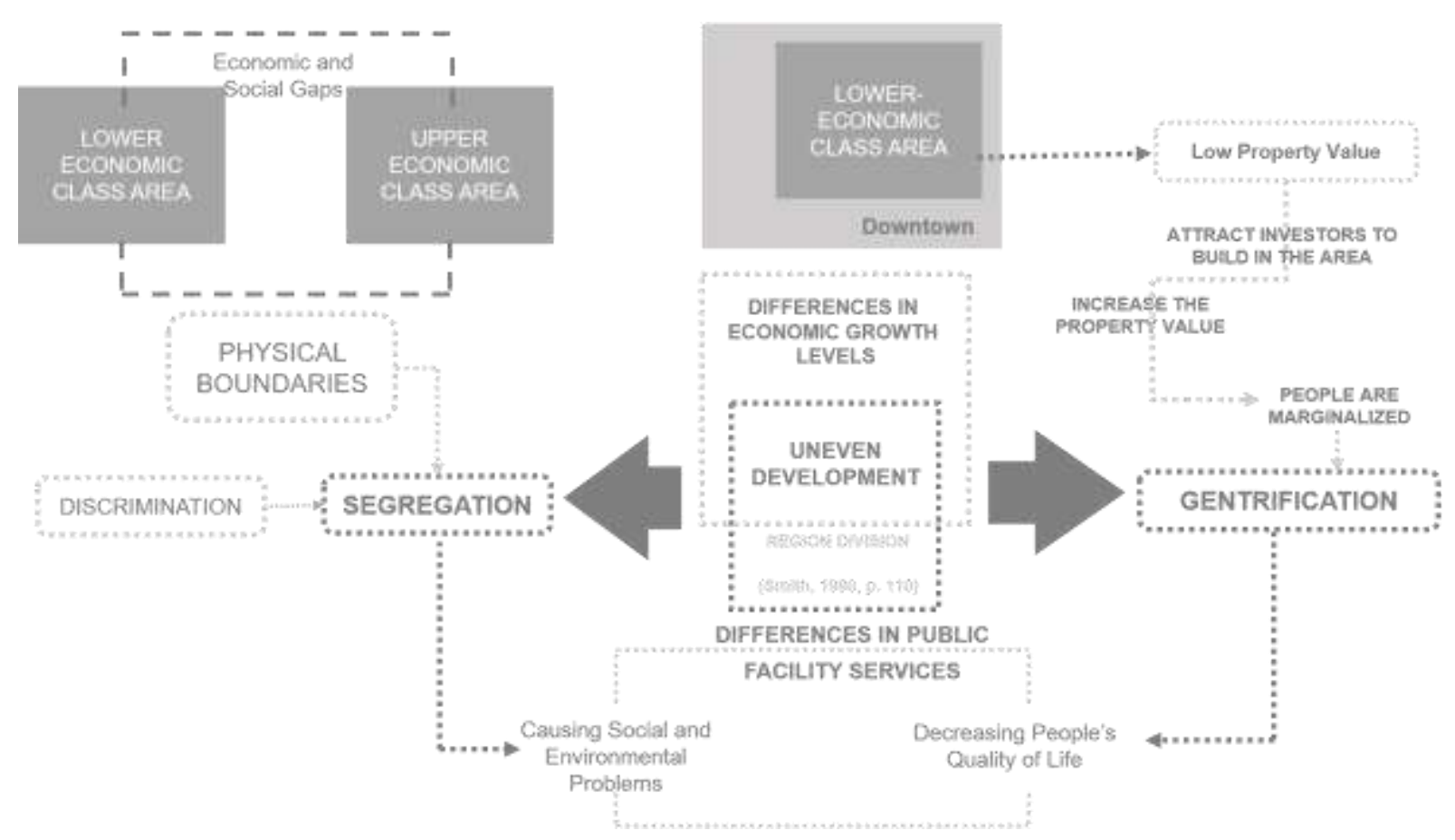

Figure 1 Theoretical framework

\section{METHODS}

We conducted a mixed-methods research study using the following: (1) a field survey to observe the physical relationship between the perumahan (formal) and kampung (informal) settlements; (2) mapping of building age and land use patterns; (3) interviews with key respondents, community leaders, street vendors, and market vendors.

\subsection{Field Observation}

We conducted field surveys to observe, compare, and contrast the following aspects of formal and informal settlements in Cikini: road accessibility, public facilities, housing density, and land use. We observed access to the settlement to evaluate the connectivity between formal and informal settlements and the surrounding area.

\subsection{Mapping}

We mapped building age and land use patterns to observe the relationship between the built and social environments. We marked different buildings, their ages, and land use to evaluate the diversity of buildings and their inhabitants. This was also a useful method to evaluate indications of gentrification.

\subsection{Interviews}

Interviews were conducted to identify differences in the production processes carried out by each food and parcel trader in Cikini. Interviews also filled data gaps that could not be obtained from the visual observations and mapping, such as the role of the community and government in supporting efforts to overcome social problems in formal and informal settlement communities. In April 2018, we used open-ended interviews with three types of respondents: residents, community leaders, and informal merchants. The following table summarizes our interview subjects. 
Table 1 List of interview subjects

\begin{tabular}{clc}
\hline No & \multicolumn{1}{c}{ Occupation } & Interview Duration \\
\hline 1 & Manual laborer & 15 minutes \\
2 & Merchant & 15 minutes \\
3 & Merchant & 10 minutes \\
4 & Merchant & 10 minutes \\
5 & Merchant & 15 minutes \\
6 & House Assistant & 15 minutes \\
7 & Community Leader & 45 minutes \\
8 & Housewife & 15 minutes \\
9 & Domestic Assistant & 10 minutes \\
10 & Merchant & 20 minutes \\
\hline
\end{tabular}

\begin{tabular}{clc}
\hline No & \multicolumn{1}{c}{ Job Type } & Interview Duration \\
\hline 11 & Community Leader & 30 minutes \\
12 & Boarding Owner & 25 minutes \\
13 & Student & 15 minutes \\
14 & Employee & 10 minutes \\
15 & Housewife & 18 minutes \\
16 & Craftsmen & 15 minutes \\
17 & Community Leader & 30 minutes \\
18 & Retired & 40 minutes \\
19 & Student & 20 minutes \\
20 & Student & 20 minutes \\
\hline
\end{tabular}

\section{RESULTS AND DISCUSSION}

Cikini is a downtown area with a commercial area and office area. It has its own train station for commuting purposes and access to the area. The commercial area is located across the informal and formal settlements while the office area is located across from and within the formal settlement. There are supporting facilities such as schools, hospitals, and universities. Due to the area development and surrounding facilities, there is a difference in economic growth of Cikini and the surrounding area, such as high selling prices in the area around the informal settlement.

The difference is apparent in the low economic growth rate of the informal area, Kampung Cikini Ampiun. The kampung has higher population density than the formal settlement. Its low economic growth rate impacts the property value, attracting many people to live there.

The residents' economic growth is related to their ability to compete with the outsiders who come to Cikini to work. Cikini is easily accessible by the train and the main road, which attracts many outsiders. There is tight competition between the residents and the outsiders for jobs. Unfortunately, only those who reside in the formal settlement have the skills required for whitecollar jobs; the informal settlement residents are relegated to low paying work due to their lack of skill. The residents' inability to fulfill their own basic needs (food and housing) also affects the economic growth rate. These two points show that economic growth is highly related to residents' skill.

Another difference between the formal and informal settlement is the division of the working class and the production process. To explore this difference, we looked at the parcel industry found in Cikini. We found out that location and expertise play an important role in determining the worker's social class and pay grade.

Years ago, parcel merchants sold their wares along the sidewalk of Cikini station. Then in 2014, they moved to the Cikini Gold Center (CGC), a modern market managed by Badan Usaha Milik Daerah (a local government-owned enterprise). The merchants usually import their materials and arrange their parcels in front of their kiosks. The building corridor serves as their production space and display space to attract buyers.

Unfortunately, the move to the CGC has lowered the sales rate for parcel merchants. Even though CGC has better facilities to support buyers' comfort, it removes the easy access to merchants that customers used to have when the merchants opened their kiosks on the sidewalk. Customers must visit CGC in order to visit the parcel merchants. This inconvenience discourages buyers from visiting the parcel merchants. A 32 year old parcel craftsman named 
Abun claimed that his sales rate is much lower than before. The GCG has failed to develop the productivity of parcel industry in Cikini.

The difference in the economic growth rate affects the quality of public facilities in Cikini. The development in the kampung is worse than the formal settlement. Inequalities can be seen in the availability of clean water, electricity, and waste management. The residents in the kampung use groundwater because they cannot afford the clean water provided by the government. Fortunately, they can still afford electricity (which is also provided by the government). There is no garbage treatment plant or any effort to treat trash before the residents throw it away. The trash is collected at a temporary shelter before it is brought to a disposal site. Some of the residents burn their trash.

There is a clear social class division between the formal and informal settlements based on the workers expertise levels. Parcel merchants are considered low-class workers while white-collar workers are considered high-class. Social class division affects the workers' income, cementing the social class division in Cikini.

The social class division also makes it harder for residents in the informal settlement to get a bank loan because they usually do not have a steady income. This illustrates the difference in opportunity between the lower and upper class. This difference creates segregation, which is in accordance with Wilson's (2012) theory.

The social class division also affects area development, in accordance with Smith \& Harvey's (1990) uneven development theory. A wall at the back area of the formal settlement serves as a physical barrier between the informal and formal settlements. Despite the physical wall that separates them, the residents from both areas have easy access to each other area. The gate that connects the informal area and the formal area offers some opportunities for informal settlement residents to sell their wares as street vendors. This open access to the formal area affects the productivity level of Kampung Cikini Ampiun residents, but it does not have a significant impact on their income.

The wall does cause some problems. It creates a rift between the two areas that pressures the informal settlers to stay in the informal area even if this is not what they want. The wall is a physical symbol of the segregation in Cikini that is based on the difference between economic and social classes. The formal settlement, Cikini, is an upper-class area while the informal settlement, Kampung Cikini Ampiun, is a lower-class area. The gap between the formal and informal settlements' residents causes a difference in the land value of each area. Cikini Ampiun residents cannot live in the formal residential area because they cannot afford it.

Residents in the formal settlement pay a higher price to live there. The high property value of formal settlement increases the tax paid by its residents. They also need to pay for management to keep the public facilities and services running. The extra price they pay increases the quality of life and productivity of the formal settlement. Meanwhile, the residents in the informal area have no money to spare for extra services or facilities. Their public facilities are left in poor condition because there is no one to manage them. This lowers the productivity of residents, in accordance with the Massey and Denton's (2012) theory.

However, both areas can benefit from each other. As mentioned above, the residents from informal area sell their wares in the formal area. This provides the opportunity for the residents in the formal area to acquire cheaper foods.

Figure 2 below shows the division of the informal and the formal settlement. It also shows the wall and the access point to enter the informal settlement. The differences in development level can be seen in the density, access, and distribution of houses in the informal and the formal settlements. The surrounding commercial buildings and other public facilities reflect the high 
level of development around them. Due to the high level of development, the property value around the informal settlement is also high.

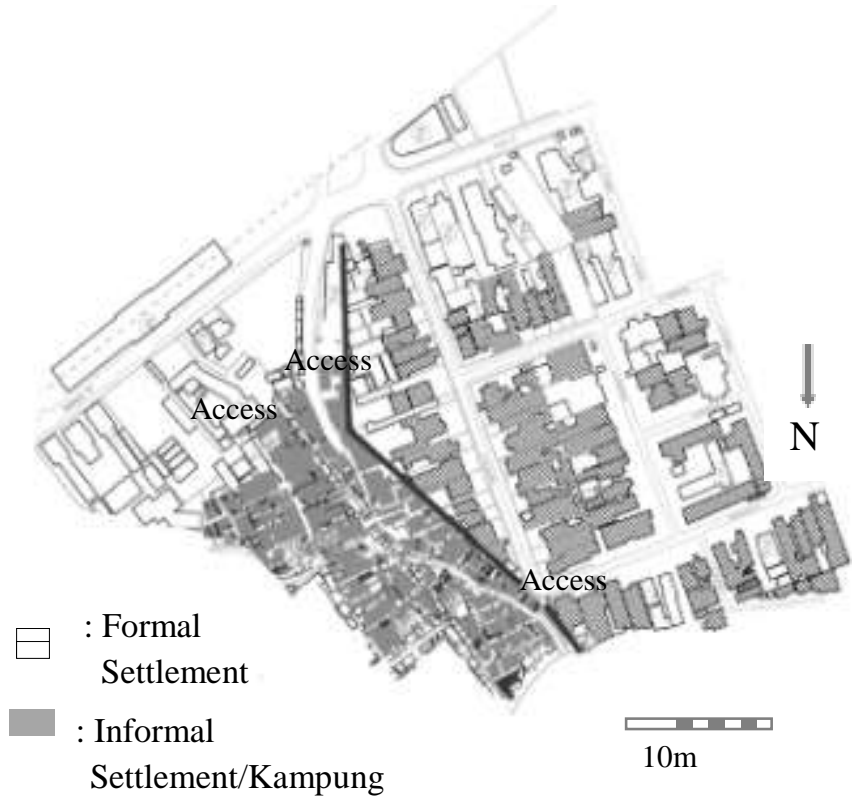

Figure 2 Division of formal settlement and informal settlement (kampung)

Segregation in Cikini contributes to the separation of the informal and formal settlements. It manifests in physical barriers that make it difficult for informal settlement residents to live in the formal settlement. The residents in informal settlement will eventually lose their spirits due to social inequality. Segregation causes a rise in the unemployment rate, which leads to poverty.

The other communities outside the informal settlement play an important role in its development. The difference in property development in both settlements shows indications of gentrification, which is in accordance with Smith's (1979) theory of gentrification. The differences can be seen in the physical condition of the houses and physical environment of Kampung Cikini Ampiun and the formal settlement. The low property value in the kampung reflects its lack of development. On the other hand, the property in the formal settlement is well developed, raising its property value.

The absence of the commodity sector in Kampung Cikini Ampiun also contributes to the decreasing value of Kampung Cikini Ampiun. There is no natural surces of food for food vendors in the kampung, denying them the chance to source their materials independently. If the residents cannot fulfill their needs on their own, they cannot improve their economic class.

In contrast to Kampung Cikini Ampiun, the formal settlement is well developed. Dams have been upgraded and pavement fixed in the area, increasing its property value. The increasing property value of the formal settlement also increases the land tax up to 10 million rupiahs. Some people can no longer afford to live there and choose to move away from the formal settlement. Their vacant houses are then bought by high-income people from within or outside the community.

Figure 3 shows the division of the Cikini formal settlement area. The area is divided into blocks by the roads. The grid-like division makes the distance taken by pedestrians from their homes to the commercial area the same as the distance taken by the vehicles. In this figure, we can see the street for pedestrians is emptier than the road for vehicles. 
Cikini formal settlement has three types of houses. The first type is a multi-story house that serves as an office. The second type is a new house, and the third type is the old house. There are stark differences between these three types that can be seen in their facade condition. The first type usually advertises an office logo. The second type is in a minimalist style, with a tall fence a good distance away from the terrace. The old house does not have a fence and is surrounded by greenery.

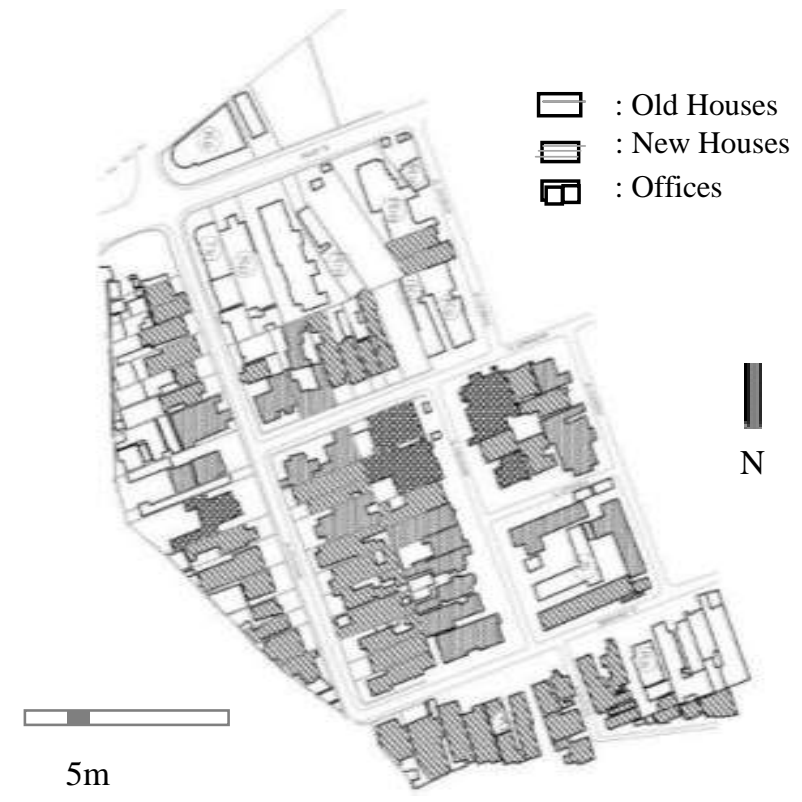

Figure 3 The mapping of formal settlement function

The emergence of offices within the settlement is due to people trying to cheat a government policy. The government does not increase land and building taxes in residential areas, so businesses houses that also serve as offices. Some older residents moved away from Cikini because they could no longer afford to pay the tax. The migration of the old residents away from the formal settlement attracts people with higher incomes to take their place (Fauzi, 2015). People with higher incomes buy vacant houses and turn them into new offices or houses for high-income people.

The lack of development in Cikini's informal settlement is indicated by its narrow roads that limit the number and type of vehicles that can pass through the kampung. Only two-wheeled vehicles that can be used there. Narrow road access is due to the high-density housing in the kampung. The high density of houses creates shades on the road in the area that provides comfort for pedestrians and that residents to use as a gathering area.

Most of the houses in the kampung do not have a fence, thus increasing the interaction between neighbors. The limited interior space drives people to use their exterior space, which is more comfortable due to the shade provided by the surrounding buildings. The informal settlement is adjacent to the formal settlement, so some houses face the tall wall built by formal settlement residents. The characteristic of the informal settlement is shown in the Table 2.

As of 2011, the ownership status of most houses in the informal settlement had passed from generation to generation. Up to $35.1 \%$ of the houses in RW 01 were more than 50 years old, $10.5 \%$ were between 46 and 50 years old, and the rest had been occupied for 0 to 45 years. The average house's age was 37.8 years old; the oldest was 80 years, and the newest was 1 year. Brick material was used for $95.2 \%$ of the houses (Kato, 2012). 
Table 2 Characteristics of informal house in Cikini

\begin{tabular}{|c|c|c|c|}
\hline No. & Characteristics & Category & Percentage \\
\hline \multirow{2}{*}{1} & \multirow{2}{*}{ Building Owner } & Member of household & $81.6 \%$ \\
\hline & & Other individual & $18.4 \%$ \\
\hline \multirow{4}{*}{2} & \multirow{4}{*}{$\begin{array}{l}\text { Acquisition of Building } \\
\text { (for those who own) }\end{array}$} & Built from scratch & $17.2 \%$ \\
\hline & & Renovated an old house & $3.2 \%$ \\
\hline & & Bought a new house & $14.0 \%$ \\
\hline & & Bought an existing house & $65.6 \%$ \\
\hline \multirow[b]{2}{*}{3} & \multirow{2}{*}{ Structure of House } & Wood & $14.4 \%$ \\
\hline & & Brick & $95.2 \%$ \\
\hline \multirow{9}{*}{4} & \multirow{9}{*}{$\begin{array}{l}\text { Material of House and } \\
\text { Roof }\end{array}$} & Tile & $0.5 \%$ \\
\hline & & Cement & $40.3 \%$ \\
\hline & & Clay & $1.5 \%$ \\
\hline & & Brick & $45.8 \%$ \\
\hline & & Triplex & $4.0 \%$ \\
\hline & & Sand & $1.5 \%$ \\
\hline & & Wood & $4.5 \%$ \\
\hline & & Asbestos & $56.3 \%$ \\
\hline & & Roof tile & $0.7 \%$ \\
\hline \multirow{5}{*}{5} & \multirow{5}{*}{ Age of House (years) } & $0-5$ & $14.9 \%$ \\
\hline & & $6-10$ & $8.8 \%$ \\
\hline & & $41-45$ & $5.3 \%$ \\
\hline & & $46-50$ & $10.5 \%$ \\
\hline & & Over 50 & $35.1 \%$ \\
\hline
\end{tabular}

As of 2011, up to 64.9\% of the built-area of Kampung Cikini Ampiun was houses smaller than $50 \mathrm{~m}^{2}$ (Kato, 2012). With an area of less than $50 \mathrm{~m}^{2}$, these houses are not subjected to land and building taxes (Rudi, 2016). The absence of land and building tax raise the threat of eviction at any time. On the other hand, the cheap property rates in Kampung Cikini Ampiun allow the lower class to own or rent a property in downtown Jakarta. Low rental prices also lower the price of products in Cikini, making products more affordable for all circles of society.

The high property rental rates in the Cikini region drives some merchants to sell their wares on the sidewalk. Vendors use the sidewalk space and empty lots to offer affordable products that meet people's needs. The availability of land for street vendors also maintains the income of the informal settlement residents who work as street vendors.

Property development in the Cikini region is dependent on government regulations. The government as a policymaker should adjust property development permits in accordance with the potential found within a community. The government can provide compensation to take care of the Cikini people and the workers.

The current property development in the kampung ignores the main social problems. Property development in Cikini shows a lack of attention to the local communities and the working class. Property development in Cikini's informal settlement that does not consider local communities and the working class generates social problems, such as poverty and unemployment.

\section{CONCLUSION}

This research finds that, in theory, Cikini's economic growth rate depends on its people's skills. The difference in the level of expertise between the informal settlement residents and the formal settlement residents generate socio-economic inequalities, contributing to physical boundaries between the areas. The separation of the informal and the formal settlements is a form of 
segregation. However, segregation in Cikini is not based on discrimination, but on the difference of opportunity to access better public facilities and services. Although street vendors can enter the formal settlement area, they can only sell their products on the sidewalk. These differences in opportunity increase the socio-economic gap, thereby preventing the informal settlement residents from living in the formal settlement due to the high property value and price. This shows that segregation in Cikini occurs because of the differences between the economic growth rate of the informal and formal settlement of Cikini.

Our finding challenges Smith's (1979) theory that gentrification occurs because the informal settlement in the downtown area attract investors. However, some of the properties in the kampung that have been repaired still belong to the informal settlement residents. Some property improvements in Cikini's kampung provides low-cost rental houses to new kampung residents but does not indicate gentrification of the area. On the other hand, the formal settlement has a comparatively high amount of regional development, thus increasing the property values. The increase in property value and tax in the formal settlement drives some of its residents to move away. The houses that are left behind are then purchased and transformed into new offices or houses for people with higher income.

\section{ACKNOWLEDGEMENT}

This work is supported by Hibah PITTA 2018 and funded by DRPM Universitas Indonesia No. 2365/UN2.R3.1/HKP.05.00/2018. The authors remain responsible for the content of this paper.

\section{REFERENCES}

Fauzi, I., 2015. Menteng, Kawasan Elit di Jakarta yang Dilematis (Menteng, Dilemmatic Elite Area in Jakarta). Available Online at http://news.metrotvnews.com/read/2015/06/23/407063/menteng-kawasan-elit-di-jakartayang-dilematis, Accessed on February 26, 2018

Hardoy, J.E., Satterthwaite, D., 1991. Environmental Problems of Third World Cities: A Global Issue Ignored? Public Administration and Development, Volume 11(4), pp. 341-361

Herbert, C.E., McCue, D.T., Sanchez-Moyano, R., 2013. Is Homeownership Still an Effective Means of Building Wealth for Low-income and Minority Households? (Was it Ever?). Joint Center for Housing Studies, Harvard University, Massachusetts, pp.1-55

Kato, H., 2012. Report of Preparatory Survey in Cikini. Research Institute for Humanity and Nature, Kyoto, Japan

Massey, D., Denton, N., 2012. The Continuing Causes of Segregation. In: The Blackwell City Reader, Bridge, G., Watson, S., (eds.), John Wiley and Sons Ltd., Chichester, United Kingdom, pp. 177-183

Rudi, A., 2016. Ini Kategori Rumah yang Berhak Dapat Pembebasan PBB (This is a Category of Houses that are Entitled to Obtain UN Exemption). Available Online at https://megapolitan.kompas.com/read/2016/02/16/07080041/ini.kategori.rumah.yang.berha k.dapat.pembebasan.PBB, Accessed on February 26, 2018

Slater, T., 2017. Clarifying Neil Smith's Rent Gap Theory of Gentrification. Tracce Urbane, Volume 1, pp. 83-101

Smith, N., 1979. Toward a Theory of Gentrification: A Back to the City Movement by Capital, Not People. Journal of the American Planning Association, Volume 45(4), pp. 538-548

Smith, N., Harvey, D., 1990. Uneven Development: Nature, Capital, and the Production of Space. University of Georgia Press, Athens, London

Wilson, W.J., 2012. The Truly Disadvantaged: The Inner City, the Underclass, and Public Policy. In: The Blackwell City Reader, Bridge, G., Watson, S., (eds.), John Wiley and Sons Ltd., Chichester, United Kingdom, pp. 186-191 